\title{
Land Control, Authority and Political Economy, and a Planned Petroleum Infrastructure Project in Timor- Leste
}

\author{
Alex Grainger, University of Kent, United Kingdom
}

\begin{abstract}
Land in Timor-Leste had been a subject of national importance even before the government first announced a planned petroleum infrastructure 'mega-project' in 2009, the 'Tasi Mane' project, on the country's south coast in Suai, Betano and Beaco. This project has brought again into sharp relief the question of land and its control. Much recent work has focussed on land grabs' or how foreign capital and the state have played a significant role in dispossessing smallholders of arable land in other settings. This paper highlights three aspects which are inherent in the process of control. First, authority lies at the heart of land control alongside political-economic factors that lead to relocation of residents from land in project areas. Second, problems of recognition of land rights in project areas have led to more strident claims to authority locally. This issue I demonstrate by showing the historical legacy of two communities that occupy Beaco land. Third, the case study of the two comunities sheds light on the social relations inherent in local property relations and subsequent disputes catalysed by contests over land control.
\end{abstract}

Keywords: Land; Political Economy; Authority; Dispossession; Infrastructure; TimorLeste.

\section{INTRODUCTION}

This article elaborates on an argument that land control requires consideration of economic and non-economic factors (the latter including legal and social factors) in the context of a petroleum infrastructure project in Timor-Leste. In section one, I introduce the general context of land in Timor-Leste including issues raised by returning to land since independence and problems of implementing land law. Section two discusses recent theoretical approaches to land dispossession by the state or foreign capital, and argues that an analysis of land control is incomplete if not treated alongside questions of authority formation which often precede 'land grabs'. Section three provides context on the developmental trajectory of Timor-Leste since independence, in particular the role of oil and gas and the Tasi Mane project in this regard. Section four elaborates on the case study by providing brief historical context on Beaco, one of three project sites. This instantiates the main argument by showing how both economic and non-economic 
Land Control, Authority and Political Economy, and aPlannedPetroleum Infrastructure Project in Timor-Leste

factors are brought to bear in terms of land control, the latter being important in explaining inter-communal relations.

\section{Land Rights, Codified Law, Customary Tenure and the Mega-Project in Timor-Leste}

Timor-Leste is a small, half-island nation that declared independence in May 2002 following a UN-sponsored Transitional Administration (UNTAET). UNTAET governed after September 1999 in the wake of a referendum on Indonesian rule in which 78.5\% of the population voted for independence. Faced with significant challenges in terms of rebuilding $90 \%$ of infrastructure destroyed by departing Indonesian military and militia members and forming a public administration, and other branches of government, the state was until 2006 largely reliant on foreign aid to shore up its budget. In 2006, TimorLeste experienced a crisis which had its roots in the military in combination with unresolved tensions among elites dating back to the resistance era. This was played out against the backdrop of land disputes among the population at large.

Following the Indonesian departure, many individuals returned to land from which they had been displaced under Indonesian occupation. Customary land tenure arrangements were asserted after independence and have been well documented in conjunction with a post-independence 'revitalisation' of culture. ${ }^{1}$ Such customary arrangements have largely been viewed as facilitating the sharing of land and resources. ${ }^{2}$ Those who did not originally inhabit land or were moved to land by the Indonesian authorities have often remained with or without the agreement of the 'original' landowners. The assertions of ownership by original inhabitants to land from which they had been displaced revealed competitions and even antagonisms among communities eager to establish relative social standing. ${ }^{3}$

The question of land control in Timor-Leste is complicated by the existence of several different legal regimes (including the Portuguese period) implemented under successive periods of colonialism. ${ }^{4}$ In the contemporary period, a hybrid legal regime has emerged out of multiple sets of laws of previous (colonial and UN) administrations. Local courts have difficulties in interpreting these laws, a factor which makes disputes

1 Andrew McWilliam \& Elizabeth G Traube, Land and Life in Timor-Leste: Ethnographic Essays (ANU E Press, 2011). See also Lisa Palmer \& Demetrio do Amaral de Carvalho, "Nation building and resource management: The politics of 'nature' in Timor Leste" (2008) 39:3 Geoforum 1321.

2 Simon Batterbury et al, "Land access and livelihoods in post-conflict Timor-Leste: no magic bullets" (2015) 9:2 Int J Commons, online: 〈http://www.thecommonsjournal.org/articles/10.18352/ijc.514> .

3 Judith M Bovensiepen, The Land of Gold: Post-Conflict Recovery and Cultural Revival in Independent Timor-Leste (Cornell University, Southeast Asia Program Publications, 2015).

4 Daniel Fitzpatrick, Land Claims in East Timor (Asia Pacific Press, 2002). A Portuguese presence existed on the island of Timor from the $16^{\text {th }}$ century until 1975; a Japanese administration ruled during the Second World War; and Indonesia invaded in 1975, leaving after the casting of a proindependence vote in 1999. 
brought to court problematic to resolve. ${ }^{5}$ Claimants involved in disputes rely on a government-mediated arbitration service operating at the local level. Where this produces inconclusive outcomes or is not used, some have relied on the promise of disputes being resolved in anticipation of a recently-passed land law, some implications of which are explored below. Others have also pursued 'extra-legal' means of 'resolution' through violence, although this has largely proved to be the exception, not the rule. ${ }^{6}$

Up until mid-2017, no overarching legal framework for property rights had been enacted by post-independence governments. In 2012 parliament passed a draft land law which set out rules for establishing private property ownership. The draft law was vetoed by then president José Ramos Horta, and subject to criticism relating to customary ownership since certain of its aspects made provision to claim land on the basis of cultivating it or constructing buildings on it. Rather than seeking to recognise the legitimacy of certain existing customary arrangements, its critics argue, the draft law has attenuated them, ${ }^{7}$ although Government defenders of the law deny this. ${ }^{8}$ The latest development in codifying property ownership took place on $5^{\text {th }}$ June 2017 , when a Special Regime for the Ownership of Immovable Property (otherwise known as the 'Land Law') was passed by the sixth constitutional government (2015-2017), being approved by incoming president Francisco 'Lu-Olo' Guterres. ${ }^{9}$ The Law sets out provisions for the formalization of private property ownership through a cadastre designed to "create a market" (preamble) for land; and to clarify the terms of state ownership. State ownership of land is broadly divided into two forms-public and private. In general, public state land must meet criteria of being "indispensable...to the public interest" (article 8:2), or must be regarded as an "asset" of "public domains" (8:3), including oil and gas fields (8:3:f).

The Law defines the state's private land as in large part land previously occupied by the Portuguese or Indonesian authorities before 1999. However, it also provides the State with considerable power to claim land for other reasons. Land "without known owner" (sem dono conhecido) (9:4) automatically becomes the State's. In practice, where land is apparently "abandoned" this places a burden on individual claimants to prove ownership, especially where the land is claimed by the state on the basis that it has been abandoned. Most land does not have formal documentation to prove longterm possession because customary ownership of land predominates and because the Indonesian authorities destroyed or removed many land title documents issued before 1999.

5 Susana de Matos Viegas \& Rui Graça Feijó, "Navigating Without a Compass: State Transition in Timor-Leste's Formal Land Tenure System" in Transform Indep Timor-Leste Dyn Soc Cult Cohabitations (Taylor \& Francis, 2017).

6 Fitzpatrick, supra note 4.

7 Ibid.

8 Babo-Soares, D. 'The challenges of establishing a land tenure regime in a newly independent state' in Viegas, S.M. \& Feijó, R.G., (eds.) Transformations in Independent Timor-Leste. Dynamics of Social and Cultural Cohabitations (Routledge, 2017).

9 Lei no. 13/2017 de 5 de Junho 'Regime especial para a definição da Titularidade dos Bens Imóveis'. 

Project in Timor-Leste

The law does make two provisions for recognising "informal" title holding, which is based on continuous, long-term (of at least 20 years) undisputed possession (articles 15 \& 16). Yet this is also problematic since the rationale for "creating" informal property ownership was to correct "injustices practiced before the independence of Timor-Leste [in 2002]" (preamble), referring, inter alia, to dispossession from land by the Indonesian authorities or another party. But such dispossession is only recognised as a legitimate reason for interrupting continuous possession after 31 December 1998 (article 17:2). For disputes that arise over ownership of land occupied by the Indonesian authorities before this date, the Commission for Land and Property (Comisão de Terras e Propriedades) will make judgements on a "case-by-case" basis (article 75). Thus, rather than leaving the possibility open for customary mediation, or a full recognition of informal rights arising from historical possession, the Commission for Land and Property will make final judgments on cases arising under article $75 .{ }^{10} \mathrm{In}$ effect, the law provides fewer rights to land claimants than it does to the State. The State remains the ultimate arbiter in disputes, which might otherwise be resolved through customary mediation.

Despite its long gestation period and potentially far-reaching implications for disputes over land, I want to shift focus away from how the Law will be implemented and interpreted, instead concentrating on a case study of community relations at the local level. Nor will I attempt to predict how the Law will be applied in this case or speculate on any possible outcome. Such a study still instantiates problems which may arise from the new law by dealing with its provisions to commodify land by creating a market in it (preamble) and in regard to dispossession-but does not make the new law a central issue. This is significant since where communities and individuals have historically shared access to land, this has mainly been a matter of social relations, and not necessarily observance of codified laws. Where dispossession under Indonesian rule caused land disputes after independence, co-existence (rather than 'resolution') was often achieved in spite of no or little state intercession. Several issues are at play in the case that I examine: what about situations where the post-independence State wants to move entire communities from land that they have historically occupied? How does the compensation process-and indeed the creation of land markets now written into lawplay out? What are the potential effects of the state's expropriation on customary (informal) agreements between original land owners and occupying inhabitants? How do legacies of the past and claims to local authority affect such informal agreements? In order to address these issues, I suggest that they are best understood through the idea of how land is 'controlled', in the context of both economic and non-economic actions. In doing so, I aim to incorporate into this process the local politics of claim-making to land and authority alongside the usual agents of land control, meaning the state or foreign capital.

\section{Land Control at the Intersection of Political Economy and Law}

10 This Law Commission for Land and Property offers indemnity payments to those evicted from land as a result of losing disputes. 
The concept of dispossession, whereby those who normally subsist from land are evicted from it, is central to political economic studies which argue that dispossession represents a primary stage to land's commodification intrinsic to transitions to private property under early capitalism, or 'primitive accumulation'. ${ }^{11}$ This theme was developed by Harvey ${ }^{12}$ whose concept of 'accumulation by dispossession', has been taken up more recently to explain the role of finance especially in 'global land grabs'. ${ }^{13}$ Primitive accumulation was not associated only with the transition to capitalism in the West, but was an ongoing process whereby capital has found new outlets in the form of land in the 'Third World'. Such 'land grabs' typically, but not exclusively, involve investment by private and state interests from rich or middle-income countries overseas to satisfy 'food security' objectives, meaning using land acquired to cultivate food for domestic consumption at a lower cost. These interests rent or purchase arable land in 'the South' for this purpose - East Africa, East Asia and to some extent Latin America being recent prominent destinations for such investment.

Scholars have identified features which they argue make 'global land grabs' both contingent upon and resemble land expropriation that has taken place historically. Some argue that the driving force behind land grabs is often global finance capital, which fundamentally determines the nature of the 'grab'. They suggest that land grabs also have a particular, contemporary character as the result of a convergence of a series of global crises, related to food and energy, climate change, and the rush by global finance to find 'safe havens' for capital. ${ }^{14}$ Still others believe that land grabs focus on a definition of dispossession that privileges the role of global finance capital. Foreign capital is not always the engine of land dispossession with local political-economic reasons for dispossession just as important, (for example the desire of wealthy peasants to expand their acreage).${ }^{15}$ Others have questioned the contemporary nature of land grabs arguing that foreign acquisition of land has been going on for hundreds of years, ${ }^{16}$ or that 'land grab' has become a "catch-allphrase". ${ }^{17}$ Others argue that the economic reasons for dispossession may be varied and not always relate to arable land, but also state facilitation of land used for mega-projects such as special economic zones (SEZs). ${ }^{18}$

11 Marx, K. Capital. A Critical Analysis of Capitalist Production, volumes 1\&2 London: Wordsworth, 2013.

12 Harvey, D. The Limits to Capital London: Verso, 2006 [1982]; Harvey, D A Brief History of Neoliberalism, Oxford University Press, 2007, pp.159-160.

13 Hall, D. 'Primitive Accumulation, Accumulation by Dispossession and the Global Land Grab'. Third World Quarterly, 43:9 1582-1604, 2013.

14 McMichael, P. 'Introduction, Food, Energy, Environment: Crisis of the Modern World-System' pp.95102, in Review (Fernand Braudel Center) vol.33, (2/3), 2010.

15 Hall, D. 2011. 'Land Grabs, Land Control, and Southeast Asian Crop Booms'. The Journal of Peasant Studies. 38 (4): 811-831.

16 Kugelman, M. and Levenstein S.L. The Global Farms Race. Land Grabs, Agricultural Investment, and the Scramble for Food Security Island Press, 2012, p.8.

17 Borras, Jr., S.M. \& Franco, J. 'Global Land Grabbing and Trajectories of Agrarian Change: A Preliminary Analysis' Journal of Agrarian Change, Vol. 12 No. 1, January 2012.

18 Levien, M. 'The land question: special economic zones and the political economy of dispossession in India'. The Journal of Peasant Studies Vol. 39, 3-4, 2012. 

Project in Timor-Leste

It is unarguable that globally, the foreign acquisition of land has increased substantially in the last decade-and-a-half, and that finance has played a significant role in this process. On the other hand, land control involves questions that also relate to the non-economic domain. Another area of debate revolves around how land is grabbed through 'extra-economic' means. The latter refers to the use of force, but as Peluso and Lund have pointed out, there is also an array of factors which prefigure and contribute to dispossession which do not involve force - "new legal and practical instruments for possessing, expropriating, or challenging previous land controls". ${ }^{19}$ Land control calls for land to be understood on several levels, scholars argue - at the minimum as 'territory' or 'property' - as Hall points out, but also as subject to regulation. ${ }^{20}$ According to Hall, Hirsch and Li's framework, land control can eventuate through the laws and regulations of property regimes, alongside force and the market. ${ }^{21}$ Such a focus therefore includes not merely land 'grabbed' by foreign capital but also how land is controlled through regulation and legal means more generally.

In the context of land acquisition for large-scale infrastructure projects, some scholars have pointed to the state as a prime facilitating agent ${ }^{22}$ and the salience of Scott's analysis ${ }^{23}$ that states and international financial institutions use large infrastructure projects to make territory and populations 'legible'. ${ }^{24}$ By comparison, others claim, the local case studies that Hall et.al. ${ }^{25}$ use to instantiate their work, are insufficient in showing how the state rationalises and legitimates such projects (Oliveira, 2013). ${ }^{26}$ In such readings, neither foreign capital nor local case studies alone can explain land acquisition, but require proper consideration of the power of the state and the ways that such power is made legitimate through being made material. While infrastructure is indeed a crucial way that the state legitimates its authority, I argue that such infrastructure projects also often catalyse claims to authority at the local level, especially where land ownership is at stake.

Land control therefore requires understanding how authority works at different levels and different perspectives alongside economic reasons for dispossession. Conventional understandings of the relationship between authority and political

19 Peluso N.L. \& Lund, C. 'New frontiers of land control: Introduction', The Journal of Peasant Studies, 38:4, p.668.

20 Hall, D. Land, Polity Press, 2012.

21 Hall, D., Hirsch P. and Murray Li, T. 2011. Powers of Exclusion: Land Dilemmas in Southeast Asia. Singapore: National University of Singapore Press.

22 Wolford, W. Borras, Jr. S.M., Hall, R., Scoones I. and White. B. 'Governinggloballanddeals: the role of the state in the rush forland'in Wolford,W. Borras, Jr. S.M., Hall, R., Scoones I. and White. B. (eds.) Governinggloballanddeals: the role of the state in the rush forland' Chichester, West Sussex: John Wiley \& Sons, Ltd., 2013.

23 Scott, J.C. Seeing like a State: How certain schemes to improve the human condition have failed Yale University Press, 1998.

24 Grandia, L. 'Road Mapping: Mega Projects and Land Grabs in the Northern Guatemalan Lowlands' in Wolford,W. et.al. supra note 22.

25 Hall et.al., supra note 21.

26 Oliveira, G de L.T. 'Land Regularization in Brazil and the Global Land Grab' in Wolford, W. et.al., supra note 22. 
economy in the context of land control posit that private property rights, when guaranteed by the state, will provide the necessary conditions for economic development through land markets where communal land arrangements do not. ${ }^{27}$ By contrast, but still from the institutional perspective, others argue that collective-based local institutions rather than the state or private interests make more efficient use of land and its resources. ${ }^{28}$

I would like instead to emphasise that local people claim and consolidate authority in order to make claims to land with processes of land titling acting as a catalyst. ${ }^{29} \mathrm{In}$ highlighting this aspect I aim to show a different configuration of political-economic and legal factors that attends land control. ${ }^{30}$ Property can become contested long before it is titled, through the "daily interactions" of groups and individuals who use land and its resources. I thus take the concept of 'control rights' to mean "the capacity to define the core elements of property relationships: the actors considered to be able to take part in property relationships, the object considered to possess material value, and the relationships considered legitimate" ${ }^{31}$ Control rights show how questions of land control are "as much about the scope and constitution of authority as about access to resources...”. ${ }^{32}$

I will examine a case where monetary compensation and claims to authority have emerged from negotiations over the status of land to be used for the Tasi Mane petroleum infrastructure project. This case illustrates that where the state or other powerful interests begin a process of commodifying land, contentions over authority at a local level may become more pronounced. I argue that such authority never simply appears as if prompted by such a top-down process; rather it pre-exists as a result of historical processes. But claims to authority coalesce as questions of who owns land loom larger. The next section sets out the general context of bilateral oil and gas Agreements which made the Tasi Mane project possible to imagine for Timor-Leste's State elites.

\section{Timor Sea Oil and Gas, the Tasi Mane Project and National Development}

This section first explains the significance of Agreements between Timor-Leste and Australia which divided revenues from oil and gas in the Timor Sea. It then outlines the

27 Larsson, T. Land and loyalty: security and the development of property rights in Thailand. Ithaca: Cornell University Press, 2012, p.1; Boone, C. Property Rights and Political Order in Africa: Land Rights and the Structure of Politics, Cambridge University Press, 2014, p.12.

28 Ostrom, E. Governing the Commons: The Evolution of Institutions for Collective Action Cambridge University Press, 1991.

29 Sikor, T. Lund, C. The Politics of Possession: Property, Authority, and Access to Natural Resources. Wiley-Blackwell 2009.

30 Gellert, P., \& Andiko. The Quest for Legal Certainty and the Reorganization of Power: Struggles over Forest Law, Permits, and Rights in Indonesia. The Journal of Asian Studies,74(3), 2015. 639-666.

31 Sikor, T, Ngiem, PT, Sowerwine, J, and Romm, J eds. Upland Transformations in Vietnam Singapore: National University of Singapore Press, 2011, p.147.

32 Sikor and Lund, supra note 29, p.2; see also von Benda Beckman, K., von Beckmann, F. and Wiber, L. Changing Properties of Property Oxford: Bergahn 2006. 

Project in Timor-Leste

circumstances under which the most significant of these agreements came to be ended by the Government of Timor-Leste. It then shows how, separately, the Government devised a plan to bring oil and gas onshore for processing and export under the Tasi Mane scheme. Finally, it discusses the existing status of land ownership for communities that will be relocated to make way for the scheme.

In March 2003, the Government of Timor-Leste and Australia concluded the Timor Sea Treaty and International Unitization Agreement (IUA) which created and governed a 'Joint Petroleum Development Area' (JPDA) in the Timor Sea, establishing an exploration, extraction, and revenue-sharing regime. The JPDA included the Bayu Undan field, discovered in 1995, and about a fifth of the Greater Sunrise natural gas field discovered in 1974. In December 2005, the Governments passed 'Certain Maritime Arrangements on the Timor Sea' (CMATS).${ }^{33}$ CMATS divided JPDA revenues equally between Australia and Timor-Leste, thus providing the majority of Timor-Leste's state income (of around US\$100 million a month in 2006) with revenue coming for the most part from Bayu Undan.

Since Greater Sunrise straddled the border of the JPDA, it could only be explored once "unitized" under the IUA (meaning smaller fields would be treated as one large field to make them commercially viable). However, most of Greater Sunrise lay outside the JPDA in an area claimed by Australia as within its maritime boundaries but disputed by Timor-Leste. Since the duration of CMATS was 50 years, during which time no discussions on the status of maritime boundaries could take place (Article 4), the field remained unexplored. However, the Agreement could be unilaterally cancelled if production had not been begun within 10 years (Article 12). Timor-Leste chose to take this course in January 2017, through a "denunciation" ${ }^{34}$ of CMATS, thus falling back on the terms of the earlier Timor Sea Treaty. ${ }^{35}$

Timor-Leste further resolved to press Australia to negotiate maritime boundaries since it had come to light that Australia's intelligence services had spied on Timor-Leste during the CMATS negotiations. In December 2013, Timor-Leste began action against Australia at the International Court of Justice (ICJ) in relation to the CMATS espionage. In April 2016, Timor-Leste also initiated compulsory conciliation proceedings against Australia (under UNCLOS, Annex V, Article 298) at the Permanent Court of Arbitration (PCA), which Australia agreed to enter into. In order to improve relations, Timor-Leste subsequently agreed to withdraw its espionage claim from the PCA in early 2017, a move that appears to have paved the way towards the 'Copenhagen Agreement' on maritime boundaries in September of the same year, the details of which remain undisclosed.

In the interim, beginning in 2009, the Government of Timor-Leste commissioned a number of feasibility studies on the possibility of building oil and gas refining and storage infrastructure on three locations on the south coast. The 'Tasi Mane', (or "south

33 'Treaty between The Government of Australia and The Government of the Democratic Republic of Timor-Leste on Certain Maritime Arrangements in the Timor Sea' (CMATS), 2006.

34 Decreto do Presidente da República no. 01/2017 de 16 de Janeiro.

35 'Timor Sea Treaty between The Government of East Timor and The Government of Australia", (TST) 2003 
sea") project was planned to be constructed initially from the proceeds of Bayu Undan oil and gas which was deposited into a sovereign wealth fund, from where most of the State's annual budget was drawn. By 2011, the state had put forward a plan to build Tasi Mane in order to attract foreign-producedoil for processing in the country as an important part of itsNational DevelopmentPlan of that year.

As part of the plan, Bayu Undan's oil and gas would be brought onshore to a refinery at Betano, displacing about 2600 people. ${ }^{36}$ Under the plans, Greater Sunrise natural gas would be brought along a three kilometre-deep pipeline to Beaco, where it would be converted into liquefied natural gas (LNG). The LNG plant at Beaco would necessitate the displacement of about 850 people. A third site, at Suai, near the Indonesian border, is most developed of all, and principally the site of a 'supply base' to store processed oil and gas and supply logistical and technical support to the other sites, and an airport. All three sites are planned to be connected by a multi-lane highway of about $160 \mathrm{kms}$ in length. Beside the highway will run a pipeline transporting Beaco's LNG to Suai. The Tasi Mane project thus clearly feeds into a vision of infrastructure-

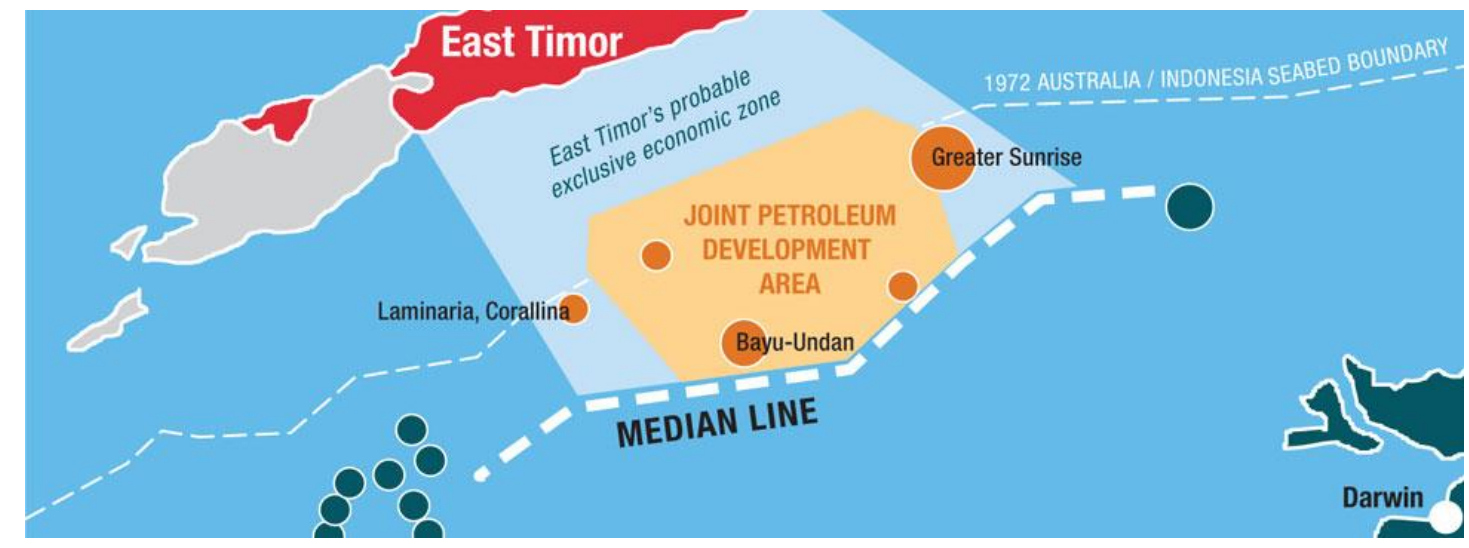

driven economic development laid out since at least 2009.

Source: timfo.org

The effect of the project on land ownership of local communities so far remains ultimately unclear in two of the three project sites even with the enactment of the Land Law of 2017, as mentioned above. In Betano, the process of registering land ownership, much less the compensation of residents whose land will be affected, is far from complete. Suai is the only location where a significant relocation of communities and construction work has been carried out. In 2013, the Government negotiated with its community leaders "in secret" who signed over more than 1000 hectares of land in exchange for 10 percent of profits from the town's 'Supply Base'. ${ }^{37}$ As the anthropologist

36 From 2015 census figures, available at http://www.statistics.gov.tl/category/publications/censuspublications/2015-census-publications/volume-2-population-distribution-by-administrative/. Downloaded 28 September 2017.

37 Cryan, M. 'Impacts of the Suai Supply Base Project in Timor-Leste' State, Society and Governance in Melanesia Program, Australian National University. http://ssgm.bellschool.anu.edu.au/expertspublications/publications/4112/impacts-suai-supply-base-project-timor-leste; downloaded on November 262017. 

Project in Timor-Leste

Judith Bovensiepen emphasizes ${ }^{38}$, such deals have been framed as not only a matter of monetary exchange. The Government has also aimed to secure the compliance of traditional leaders, by promising them that via customary property ownership, they may "give" their land to the Government thus preventing its sale and eternal surrender, despite large infrastructure being located on the land. In exchange leaders provide legitimacy for land acquisition and the project more generally. Both sides thereafter have asserted that local communities will still "own" land that they will be compensated for.

This article is based on fieldwork that we conducted in Beaco in 2017, including 20 interviews. Our fieldwork points to several factors which can explain the complexity of the effects of land acquisition on Beaco's affected communities. First, they have been promised social benefits in the form of new housing and schooling facilities. Second, compensation promised to affected communities is not only an inducement to those affected; compensation commodifies land and has the potential to create landlessness and land speculation. Third, infrastructure 'mega-projects' such as Tasi Mane require the complete transformation of arable land for use as project sites. As Levien points out, affected communities experience a "dramatic commodification of land", ${ }^{39}$ leading to their marginalization. The Tasi Mane site fits such a pattern, and not a "land grab" pattern, since under the latter arable land will not be purchased and retained by a large company with former-subsistence farmers continuing to live on land as tenants. In the Tasi Mane project sites, the early stages of 'parcellizing' land (by which I mean its measurement in order to provide compensation to smallholders) has served to bring land ownership to affected communities' attention and in some cases has become a source of tensions.

Fourth, local communities address such tensions over land by asserting authority over it before the state has actually begun the process of parcellization. The next section provides a historical overview of Beaco, with special reference to a group settled there during the period of Indonesian rule.

\section{Beaco's planned LNG-processing facility}

The use and management of land in Beaco has been influenced by the history of settlement in the area following successive periods of colonial rule, and its contemporary legacies. In light of current plans to build an LNG facility on the suco, I first briefly outline the history of colonial-initiated settlement in the area from around the mid-twentieth century. I then draw attention to potential problems with existing arrangements to compensate the affected population and to provide social benefits before presenting an account of how this picture is made more complex in light of relations between two local groups, one of which was settled there by Indonesian forces. These historical settlements and contemporary intra-communal relations are key to understanding how authority has been claimed and legitimated against the backdrop of both communities' planned relocation.

38 Bovensiepen, J. 'Does oil have an 'owner'? From heterotopia to resource antagonism in Timor-Leste's emergent petroleum development boom’ Draft article typescript, 6 December 2016.

39 Levien, supra note 18, p.938. 
Beaco (sometimes written in Tetun as 'Beasu') is a small village of about 850 people within the aldeia of Maluru, in Viqueque subdistrict of the district of the same name. As the planned site of the Tasi Mane project's LNG processing plant, all Beaco residents will be directly affected by the project and required to move from their land to a purpose built town about $5 \mathrm{kms}$ to the north, known as Novo Beaco. Under project plans, ships transporting LNG will offload their cargo in Beaco and most of the south of the village will be submerged under water and transformed into a harbour, with enough capacity to accommodate an LNG processing plant.

Like the other Tasi Mane project sites of Beaco and Suai, access by sea was previously gained by oil prospectors from the Timor Oil Company in the 1960s, a partAustralian and Portuguese-owned company with exclusive prospecting rights until the early 1970s. ${ }^{40}$ Community tensions over land ownership in Beaco are much less pronounced than in Uatolari, a more densely-populated area to the east. There, land tensions originated in the colonial-sponsored clearance of forested land under the banner of a rice cultivation programme. Under the program, skilled rice cultivators of the upper slopes of Mount Matebian, East Timor's principal mountain, found work cultivating the cleared rice plains. ${ }^{41}$ Reportedly, several such settlers and others acquired large tracts of land and enlisted others to clear and work on the land, which caused tensions with other settlers. This situation was exacerbated in Uatolari by the perception that the Naueti, an ethno-linguistic group previously moved to the area to cultivate rice, collaborated with Portuguese, then Indonesian authorities. In the preinvasion period, Naueti political allegiances are reported to have been to the proIndonesian party, Apodeti. By contrast, a larger ethno-linguistic group partly moved to the area by the Portuguese authorities for purposes of cultivation, the Macassae, leaned towards Fretilin and independence from Indonesian rule. However, as noted by others, this is a potentially misleading way of understanding the relationships between Macassae and Naueti which should rather be seen through the lens of colonial settlement policies. ${ }^{42}$

The Dailubun peninsula, which shelters Beaco's bay, appears to have made it an ideal entry point for the Indonesian navy after 1976. In terms of land access, to the west of Beaco, roads have historically been poorly maintained. This made it more difficult to travel to the district capital Viqueque, but with better connections to Uatolari district to the east. Sandwiched between the larger conurbations of Uatolari and Viqueque, and with sea access, Beaco was a convenient location for an Indonesian military-organised hamlet (daerah pemukiman). When this was established in 1976, some Naueti speakers, who live along the southeastern coastal lowlands, were settled in Beaco where they were

40 Grainger, A.T., 'The Timor Oil Company's network, 1956-1968: interacting internal and external infrastructures' in Bovensiepen, J.M. (ed.) Beyond the Resource Curse: Visions of the Future in TimorLeste After Independence Forthcoming, ANU Press, 2018; and Bovensiepen, J.M. supra note 38.

41 Metzner, J. Man and Environment in Eastern Timor. A geoecological analysis of the BaucauViqueque area as a possible basis for regional planning Development Studies, Centre, ANU Press, 1977.

42 Fitzpatrick D, McWilliam, A, Barnes, S. Property and social resilience in times of conflict. Land, Custom and Law in East Timor Farnham: Ashgate, 2012. 

Project in Timor-Leste

allocated arable land. Like Betano, therefore, the historical dynamics of land control also depended to a great degree on military force.

However, unlike the project site in Betano, Beaco did not subsequently see 'internal transmigration' by East Timorese and the creation of agricultural markets, part of what the Indonesian authorities called 'normalization' (meaning 'away from a war footing') in the 1980s. The Naueti constituted the only group of 'migrants' in the area, albeit mostly from the neighbouring village of Lughassa. Although land in Beaco was earmarked as a potential site of plantation development in the late-1970s and early-1980s, the Indonesian authorities appear not to have promoted this plan on an intensive scale, concentrating instead on neighbouring Uatolari. In Beaco, less land has been used for rice (usually indicating relative social prestige and a potentially lucrative form of cultivation). Wet rice cultivators in Beaco work land confined to the western perimeter, and the cultivated area is not large compared with neighbouring Uatolari. The main crops grown by inhabitants then, as now, included timber (particularly teak), coffee, coconuts, cassava, rice and fruit. In light of the historical conditions described above, in the next section I will turn towards potential and actual problems created by the Tasi Mane project.

\section{The Political Economy of Compensation and Changing Control Rights}

\section{Compensation, the new town, and land marginalization}

The Tasi Mane project has created several potential and actual problems in relation to compensation provided for affected populations' land. This section first highlights how although the project provides 'social benefits' to communities in the forms of new housing and schooling, it does not replace arable land. This will force affected populations to turn towards wage labour, but there are not enough jobs at the refinery or other nearby enterprises to satisfy this demand. Fundamentally, by commodifying land, the project will introduce rents and land speculation. Land prices may subsequently increase, thus risking landlessness. Second, reconciling project aims with community needs have been made more complicated by claims to authority and land between the Macassae and Naueti locally.

There are three factors that complicate the compensation of land for the Tasi Mane project: the commodification of land; the lack of available arable land at Novo Beaco; and unclear methods of compensating 'communal land'. First, land will be compensated to the value of US $\$ 3$ per $\mathrm{m}^{2}$. Among those that we interviewed in Beaco, the average of land to be compensated was 3-5.9 ha. giving sums in the range of $\$ U S 90,000$ to $\$ 180,000$. Such compensation would most likely be used to purchase further tracts of land in the vicinity of Beaco (assuming that most residents would want to purchase new land near their former places of residence). Indeed, land prices outside other planned Tasi Mane project areas have usually amounted to less than $\$ 3$ per $\mathrm{m}^{2}$. However, this situation may not continue since low land prices provide an inducement to land speculators: wealthy individuals including Government officials have already bought land adjoining project sites in Betano to generate rents from it, and may re-sell it later to 
affected communities or others at inflated prices. ${ }^{43}$ The 2017 Land Law has aimed to create a market for land, and Tasi Mane project sites may yet prove to be formative testing grounds for large-scale land commodification.

Second, affected populations are to be relocated to new housing at Novo Beaco. Novo Beaco is a large-scale new town that will require significant preparation of new housing, schooling and other facilities for the affected population. At a comparable project in Novo Suai houses have been constructed on "cramped plots" of land (Cryan 2015). Moreover, the project will limit the supply of arable land by taking over formerly arable land in Beaco without replacing it in Novo Beaco, leading to hikes in land prices. Without arable land, those affected will become wage labourers. Without arable land guaranteed in Novo Beaco, affected communities are being asked not merely to move house, but to make the transition from subsistence to wage labor: from an economy of exchange and barter in which land is usually not regarded as an asset to be dispensed with at will, to land markets and a full-blown cash economy.

The Government promised at community consultations that jobs would be created and has set up English classes in advance of relocation so that those working for the project can communicate with their future employers, or find work in spin-off industries. Indeed, many affected interviewees in Beaco expected that menial jobs would be created as a result of the project, as security guards, cleaners, or cooks. But the project is unlikely to create enough jobs to satisfy all households since the petroleum industry typically creates few new jobs and those that are created are highly specialized. The implications are that since the project does not replace arable land and does not provide alternative employment, affected communities are likely to become marginalized from land, rather than exploited on it. ${ }^{44}$ There is also a question of whether Novo Beaco, with no housebuilding underway and only a road to the planned site under partial construction by mid-2017 will be fully constructed in time for the community's relocation. Other similar such projects in Southeast Asia, for example, offer well-publicized examples of delays in installing basic infrastructure in towns built to accommodate people relocated to make way for special economic zones (SEZs). ${ }^{45}$

Third, according to the State's national census, Beaco's land tenure arrangements have different characteristics from those of other areas where the Tasi Mane project is being planned. For example, its occupants describe a quarter of land as communally

43 For example, in the neighboring Tasi Mane project site of Betano, interviewees told us that the Government's Minister in charge of electricity had purchased land in order to build apartments to accommodate project staff.

44 Levien, supra note 18.

45 See for example, details of displacement and resettlement as a result of the Kyauk Phu SEZ in Myanmar at International Commission of Jurists, 'Special Economic Zones in Myanmar and the State Duty to Protect Human Rights' downloaded 27 October 2017 at https://www.icj.org/wpcontent/uploads/2017/02/Myanmar-SEZ-assessment-Publications-Reports-Thematic-reports-2017-

ENG.pdf; and Bangkok Post, "Myanmar Advances" http://www.bangkokpost.com/news/asean/1101089/myanmar-advances. Downloaded on 3 October 2016. 

Project in Timor-Leste

owned. In Betano, the figure is $1.3 \%$, while the national average is $8 \%{ }^{46}$ This relatively high figure suggests that dividing and compensating such communal land could be more complicated than if such land were individually owned. 'Communal' land is in fact often a mixture of collectively- and individually-owned land. ${ }^{47}$ In any case, the existence of communal land relates not only to its compensation but also the authority of the community over it. Questions of who asserts such authority and why are key to understanding this factor. Below I discuss how, since the departure of Indonesian forces in 1999, one community moved to Beaco in 1976, the Naueti, have acknowledged that the land on which they reside is owned by the Macassae. In return, the Macassae have "permitted" the Naueti's access to land. However, the advent of the Tasi Mane project, has stimulated debate between and among each community about their access to land and compensation to it under the scheme, explored in more detail in the next section.

\section{CONTROL RIGHTS: ASSERTING LOCAL AUTHORITY AGAINST THE LOOMING BACKDROP OF THE PROJECT}

As I argued at the beginning of this article, land control takes place through economic and non-economic actions, with the latter including the production of authority by powerful local actors to decide on property relations. We must therefore widen an examination beyond relative sums of compensation to examine how project plans have touched off attempts to assert 'control rights'. These are: the rights to define property relationships; to participate in deliberations about property; and social relationships considered to be legitimate. The State's initiation of the Tasi Mane project has acted as a catalyst for claims to authority to be asserted in Beaco. I will illustrate this with reference to the Macassae and Naueti, paying particular attention to how each claims authority based on their differing views of each other, their own statuses as property dwellers and their differing views of compensation.

The Macassae community began re-asserting their ownership of the land in several ways. First, they invoked one of two different 'origin myths' to explain how they came to reside in Beaco first and are thus its original, legitimate owners. ${ }^{48}$ There was nothing unusual about a particular community asserting precedence to land after Timor-Leste's independence via the invocation of an origin myth. Yet it has taken on new significance in the context of the Tasi Mane project. It is part of the Macassae claim to legitimate authority over the land which will privilege the group's right to compensation. This notion of an exclusive right to property led to the assertion of special access to other

\footnotetext{
$46 \mathrm{http}: / /$ www.statistics.gov.tl/category/publications/census-publications/2015-census-publications/

47 von Benda Beckmann et.al., supra note 32

48 In the local origin myth, the 'aco' or 'asu' part of 'Beaco' refers to a dog, Builaka that long ago discovered water on Beaco's land. In one telling, the water fell into the footprints of the dog's owner, Nokokai or Nokosa, as he walked to the top of a mountain, forming a river that flowed down to Beaco and opened into the sea.
} 
resources and social benefits associated with the Tasi Mane project. For example, when asked who should be employed to work at Beaco's LNG processing plant, some of our interviewees pointedly remarked that it should include only "Beaco people". It can be inferred from this either that those not included in such a definition may be either other Timorese from outside Beaco, or the Naueti who currently reside in Beaco.

Whereas the Naueti's ancestors are buried and venerated in neighbouring Lughassa, some interviewees pointed out that since 1976, community members resident in Beaco had been buried there. Furthermore, during interviews, it became clear that since the inception of the Tasi Mane project, some Naueti were promoting the view that they were no longer sojourners in Beaco, but now permanent residents. Taken together, these factors explain why some Naueti now assert that they should receive compensation from the Government not in respect of land, but on the basis of 'valuable property' - the graves of ancestors and sacred houses (uma lisan) used to venerate them. The idea of making this claim appears to have come to Naueti leaders during a government-sponsored visit to Suai in 2014 or 2015 to see the progress of the Tasi Mane project there. Thus far, there has been no recognition by the State of claims for compensation on objects of value in Beaco such as ancestral land and sacred houses. But their recognition would signal that compensation can be extended beyond land itself to other valuable objects.

Some Naueti interviewees also invoked the Indonesian legal regime to suggest that, had Indonesian law continued to apply in the present, land that they had inhabited for five years would automatically become theirs. Such remarks were made timidly and without much conviction, however. Naueti invocations of Indonesian law remain hypothetical and are not formal, public claims to land on which some have resided for 40 years. Such circumspection is arguably because some Macassae have claimed that the Naueti 'collaborated' with colonial authorities. Some of our Naueti interviewees in turn accepted that their community had worked with the Indonesian authorities and that they had been rewarded with land in return. However, they asserted that they had equally "worked with" the clandestine resistance movement to subvert Indonesian rule. Thus, this issue can be interpreted as either Macassae revisiting a perceived historical injustice or, in the context of the Tasi Mane project, they aim to re-assert ownership to and rights to compensation for land.

The terms of state recognition of ritual authorities are a significant element in respect of how the Tasi Mane project has been locally received. In the case of Suai and Betano, a neighbouring project site, Bovensiepen has written about how the government has made an agreement with local ritual authorities as original landowners who will "give" land for the project. Betano's ritual authorities will purportedly retain spiritual authority over it. According to Bovensiepen, this arrangement shows that the state has instrumentalized ritual in order to acquire land in a number of ways including constructing a crocodile sanctuary. ${ }^{49}$ A corollary of this form of state recognition is that the state can claim legitimacy from local authority without needing to engage with lengthy, potentially disputatious land claims under existing laws. To do other could result in legal challenges by inhabitants of land, potentially threatening the basis of the

49 Bovensiepen, supra note 38 

Project in Timor-Leste

Tasi Mane project itself. By ceremonially recognizing ritual owners of land as its legitimate owners, the state has in effect left the way open to compensate affected communities through an administrative process of measuring and attributing title to individual plots of land.

Despite the possibility of compensation payments being made to both communities, and all being relocated to Novo Beaco, disputes over land ownership are unlikely to disappear, ${ }^{50}$ since social relations have their origins in colonial relocation policies. Indeed, to understand the persistence of disputes in the present one must re-visit their historical origins, including the shifting terms of control rights. Colonial legal and administrative apparatuses were "shaped by patterns of commodification and intensified by the exploitation of natural resources...". ${ }^{51}$ Thus, as noted, the Portuguese colonial authorities sought to populate the coast of Viqueque district to intensify rice yields. Under Indonesian rule, more land in the area was titled under a legal and administrative apparatus governing land ownership, which was sometimes the subject of corrupt allocation. ${ }^{52}$ In Beaco, Naueti relocation was the result of so-called "security" concerns, but the Indonesian authorities assessed the land's suitability for cultivation in a cadastral map shortly afterwards. 53

\section{CONCLUSION}

The complex claims by local residents described in this article can be summarized with reference to two problems. The first, which can be termed "political-economic" issues, is more closely related to the immediate terms of compensation and its effects on disenfranchising affected communities. The Tasi Mane project has meant that land must be compensated and therefore evaluated and measured. The second relates to questions of claims to land based on legitimation, made more complex by colonial-era settlement. Naueti and Macassae must each appeal to the authority of the state to recognize their property, whereas previously-and indeed largely peaceably since 1999-customary arrangements saw Naueti recognizing Macassae authority. Instantiating the idea that land control is effectively a combination of these processes, this article has shown how attempts to claim local authority can precede land displacement and the creation of markets. As shown above, many serious implications issue from the latter, such as marginalization and landlessness. Further research may address how the process of land commodification is affected by compensated communities whose leaders had already staked a claim to land prior to its titling.

\section{Acknowledgements}

50 Indeed, such relocation may cause disputes unable to be resolved by traditional invocations of precedence, since neither group will have previously resided in the land where Novo Beaco will be built.

51 Bernstein, H. Class Dynamics of Agrarian Change Kumarian Press, 2010.

52 Fitzpatrick, D. Land Claims in East Timor. Asia Pacific Press, 2002.

53 This and other cadastral maps from the Indonesian period are held at the Archivo Nacional de Timor-Leste in Dili. 
I would like to thank participants at the International Conference on "Human Rights in Southeast Asia: Are We Moving Backward?" organized by The Centre for Human Rights, Multiculturalism, and Migration (CHRM2) and held at University of Jember, Indonesia, 11 - 12 August 2017, where a version of this paper was first presented. I wish in particular to thank the organizing committee, especially Dr Al-Khanif; and Professor Werner Menski for his useful questions and comments on this paper. I also thank Dr Judith Bovensiepen, principal investigator of the project on which I was postdoctoral fellow during 2016-17, which this research is drawn from. I am also very grateful for the research assistance of Mr Moniz Filipe in Viqueque-obrigado barak. Any shortcomings in fact are my responsibility.

\section{BIBLIOGRAPHY}

Almeida, B. 'Navigating Without a Compass: state transition in Timor-Leste's formal land tenure system' in Viegas, S.M. \& Feijó, R.G., (eds.) Transformations in Independent Timor-Leste. Dynamics of Social and Cultural Cohabitations Routledge, 2017.

Babo-Soares, D. 'The challenges of establishing a land tenure regime in a newly independent state' in Viegas, S.M. \& Feijó, R.G., (eds.) Transformations in Independent Timor-Leste. Dynamics of Social and Cultural Cohabitations Routledge, 2017.

Bangkok Post, 'Myanmar Advances' 3 ${ }^{\text {rd }}$ October 2016.

Batterbury, S, Palmer, L.R., Reuter, T.R., de Carvalho, D. do A. Kehi, B. Cullen, A. 'Land access and livelihoods in post-conflict Timor-Leste: no magic bullets' International Journal of the Commons. 9: 2 619-647, 2015.

von Benda Beckman, K., von Beckmann, F. and Wiber, L. Changing Properties of Property Oxford: Bergahn 2006.

Bernstein, H. Class Dynamics of Agrarian Change Kumarian Press, 2010.

Boone, C. Property Rights and Political Order in Africa: Land Rights and the Structure of Politics, Cambridge University Press, 2014.

Borras, Jr., S.M. \& Franco, J. 'Global Land Grabbing and Trajectories of Agrarian Change: A Preliminary Analysis' Journal of Agrarian Change, Vol. 12 No. 1, January 2012, pp. 34-59. 
Land Control, Authority and Political Economy, and aPlannedPetroleum Infrastructure Project in Timor-Leste

Bovensiepen, J. The Land of Gold. Post-Conflict Recovery and Cultural Revival in Independent Timor-Leste Cornell University Press, Southeast Asia Program Publications, 2015.

Bovensiepen, J. 'Does oil have an 'owner'? From heterotopia to resource antagonism in Timor-Leste's emergent petroleum development boom' Draft article typescript, 6 December 2016.

Cryan, M. 'Impacts of the Suai Supply Base Project in Timor-Leste' State, Society and Governance in Melanesia Program, Australian National University. http://ssgm.bellschool.anu.edu.au/experts- publications/publications/4112/impactssuai-supply-base-project-timor-leste; downloaded on November 262017.

Fitzpatrick, D. Land Claims in East Timor. Asia Pacific Press, 2002

Fitzpatrick D, McWilliam, A, Barnes, S. Property and social resilience in times of conflict. Land, Custom and Law in East Timor Farnham: Ashgate, 2012

Gellert, P., \& Andiko. The Quest for Legal Certainty and the Reorganization of Power: Struggles over Forest Law, Permits, and Rights in Indonesia. The Journal of Asian Studies,74(3), 2015. 639-666.

Grainger, A.T., 'The Timor Oil Company's network, 1956-1968: interacting internal and external infrastructures' in Bovensiepen, J.M. (ed.) Beyond the Resource Curse: Visions of the Future in Timor-Leste After Independence Forthcoming, ANU Press, 2018.

Grandia, L. 'Road Mapping: Mega Projects and Land Grabs in the Northern Guatemalan Lowlands' in Wolford,W. Borras, Jr. S.M., Hall, R., Scoones I. and White. B. (eds.) Governing global land deals: the role of the state in the rush for land Chichester, West Sussex: John Wiley \& Sons, Ltd., 2013.

Hall, D. 2011. 'Land Grabs, Land Control, and Southeast Asian Crop Booms'. The Journal of Peasant Studies. 38 (4): 811-831.

Hall, D., Hirsch P. and Murray Li, T. 2011. Powers of Exclusion: Land Dilemmas in Southeast Asia. Singapore: National University of Singapore Press.

Hall, D. Land, Polity Press, 2012.

Hall, D. 'Primitive Accumulation, Accumulation by Dispossession and the Global Land Grab'. Third World Quarterly, 43:9 1582-1604, 2013.

Harvey, D A Brief History of Neoliberalism Oxford University Press, 2007. 
Harvey, D. The Limits to Capital London: Verso, 2006.

International Commission of Jurists 'Special Economic Zones in Myanmar and the State Duty to Protect Human Rights' 2017.

Kugelman, M. and Levenstein S.L. The Global Farms Race. Land Grabs, Agricultural Investment, and the Scramble for Food Security Island Press, 2012.

Larsson, T. Land and loyalty: security and the development of property rights in Thailand. Ithaca: Cornell University Press, 2012

Levien, M. 'The land question: special economic zones and the political economy of dispossession in India'. The Journal of Peasant Studies Vol. 39, 3-4, 2012

Lund, C. Local Politics and the Dynamics of Property in Africa Cambridge University Press, 2008.

Marx, K. Capital. A Critical Analysis of Capitalist Production, volumes 1\&2 London: Wordsworth, 2013.

McMichael, P. 'Introduction, Food, Energy, Environment: Crisis of the Modern WorldSystem' pp.95-102, in Review (Fernand Braudel Center) vol.33, No. 2/3, 2010.

McWilliam, A. and Traube, E. G. 'Land and Life in Timor-Leste: Introduction' in Land and Life in Timor-Leste: Ethnographic Essays ANU Press, 2011

Metzner, J. Man and Environment in Eastern Timor. A geoecological analysis of the Baucau-Viqueque area as a possible basis for regional planning Development Studies, Centre, ANU Press, 1977.

Oliveira, $G$ de L.T. 'Land Regularization in Brazil and the Global Land Grab' in Wolford, W. Borras, Jr. S.M., Hall, R., Scoones I. and White. B. (eds.) Governinggloballanddeals: the role of the state in the rush forland Chichester, West Sussex: John Wiley \& Sons, Ltd., 2013.

Ostrom, E. Governing the Commons: The Evolution of Institutions for Collective Action Cambridge University Press, 1991.

Palmer, L. \& Carvalho, D. do A. de 'Nation building and resource management: The politics of 'nature' in Timor Leste', Geoforum 39 1321-1332, 2008.

Peluso N.L. \& Lund, C. 'New frontiers of land control: Introduction', The Journal of Peasant Studies, 38:4, 667-681. 
Land Control, Authority and Political Economy, and aPlannedPetroleum Infrastructure Project in Timor-Leste

Scott, J.C. Seeing like a State: How certain schemes to improve the human condition have failed Yale University Press, 1998.

Sikor, T. Lund, C. The Politics of Possession: Property, Authority, and Access to Natural Resources. Wiley-Blackwell 2009.

Sikor, T, Ngiem, PT, Sowerwine, J, and Romm, J eds. Upland Transformations in Vietnam Singapore: National University of Singapore Press, 2011

Wolford, W. Borras, Jr. S.M., Hall, R., Scoones I. and White. B. 'Governinggloballanddeals: the role of the state in the rush forland'in Wolford,W. Borras, Jr. S.M., Hall, R., Scoones I. and White. B. (eds.) Governinggloballanddeals: the role of the state in the rush forland' Chichester, West Sussex : John Wiley \& Sons, Ltd., 2013.

Laws, Agreements and Reports

Decreto do Presidente da República no. 01/2017 de 16 de Janeiro

Lei no. 13/2017 de 5 de Junho 'Regime especial para a definição da Titularidade dos Bens Imóveis'

'Treaty between The Government of Australia and The Government of the Democratic Republic of Timor-Leste on Certain Maritime Arrangements in the Timor Sea' (CMATS), 2006

'Agreement between the Government of the Democratic Republic of Timor-Leste and the Government of Australia relating to the

Unitisation of the Sunrise and Troubadour Fields' (IUA) 2003

'Timor Sea Treaty between The Government of East Timor and The Government of Australia”, (TST) 2003

'Timor-Leste Strategic Development plan 2011 - 2030. Submitted to the National Parliament', 2011.

Alex Grainger is currently a Taiwan Fellow in the Center for Asia-Pacific Area Studies, Research Center for Humanities and Social Sciences (RCHSS), Academia Sinica, Taipei. He originally trained as a political scientist at London School of Economics $(\mathrm{PhD}, 2014)$ and previously taught in the Department of Politics and International Studiesat SOAS. He has also been a Research Associate in the Department of Anthropology and Conservation at the University of Kent, UK. 